\title{
PENINGKATAN KEMAMPUANMASYARAKATDALAM PENGEMBANGAN PANGAN BERBAHAN DASAR TANAMAN KELOR DI RW 8 KELURAHAN BARENG KOTA MALANG
}

\author{
Tanto Hariyanto, Jupriyono \\ Poltekkes Kemenkes Malang, Jalan Besar Ijen No 77 C Malang \\ Email: tantohariyanto@yahoo.co.id
}

\begin{abstract}
Utilization of Kelor as a form of effort to increase food security, one of which the community needs to be given training of Kelor utilization. The purpose of this activity is to increase public knowledge about the use of Kelor as other food that can be used to improve food security. The result of this activity is the significant increase in knowledge after training. In addition, the trainees have also been able to produce several types of processed Kelor food for commercialization, although only limited to working groups in the Village Bareng.
\end{abstract}

Keywords: Kelor, food security, knowledge

\begin{abstract}
Abstrak: Pemanfaatan Kelor sebagai bentuk usaha untuk meningkatkan ketahanan pangan, salah satunya masyarakat perlu diberikan pelatihan pemanfaatan Kelor. Tujuan kegiatan ini adalah meningkatkan pengetahuan masyarakat tentang pemanfaatan Kelor sebagai makanan lainnya yang dapat digunakan untuk meningkatkan ketahanan pangan. Hasil dari kegiatan ini adalah meningkatnya pengetahuan secara bermakna setelah mengikuti Pelatihan. Selain itu peserta pelatihan juga telah mampu memproduksi beberapa jenis makanan olahan Kelor untuk dikomersialkan, meski baru terbatas pada kalangan pokja di Kelurahan Bareng.
\end{abstract}

Kata Kunci: Kelor, ketahanan pangan, pengetahuan

\section{PENDAHULUAN}

Dalam beberapa tahun belakangan ini, masalah ketahanan pangan menjadi isu penting di Indonesia, dan dalam setahun belakangan ini dunia juga mulai dilanda oleh krisis pangan. Menurut Sunday Herald (12/3/2008), krisis pangan kali ini menjadi krisis global terbesar abad ke-21, yang menimpa 36 negara di dunia, termasuk Indonesia. Santosa (2008) mencatat dari pemberitaan di Kompas (21/1/2007) bahwa akibat stok yang terbatas, harga dari berbagai komoditas pangan tahun 2008 ini akan menembus level yang sangat mengkhawatirkan. Harga seluruh pangan diperkirakan tahun ini akan meningkat sampai 75\% dibandingkan tahun 2000 beberapa komoditas bahkan harganya diperkirakan akan mengalami kenaikan sampai $200 \%$. Sebagai negara agraris di Indonesia telah banyak ditemukan aneka ragam hayati yang telah terbukti dapat dijadkan sebagai sumber pangan, diantaranya adalah tanaman Kelor. Tanaman ini mudah didapatkan di Indonesia karena tumbuh secara liar dan mudah di budidayakan. Namun demikian banyak masyarakat yang masih memandang remeh terhadap tanaman Kelor. Kondisi demikian membuat masyarakat masih belum banyak yang memanfaatkan tanaman Kelor sebagai sumber pangan yang bernilai gizi tinggi.

Berdasarkan hasil penelitian Kelor merupakan bahan makanan yang tinggi zat besi dan vitamin C. Dalam 100 gram daun kelor segar terkandung 9,2 mg zat besi dan $249 \mathrm{mg}$ vitamin C (Yang, RayYu, et al, 2006) sementara itu berdasarkan DKBM (2005) daun kelor mengandung $7 \mathrm{mg}$ zat besi dan $220 \mathrm{mg}$ vitamin C per 100 gram. Daun kelor dapat dikembangkan menjadi bentuk serbuk/tepung dimana kandungan zat besinya mencapai $28,2 \mathrm{mg}$ setiap 100 gramnya namun kandungan vitamin Cnya turun hingga 17,3 mg. Hal tersebut dikarenakan sifat vitamin $\mathrm{C}$ yang mudah teroksidasi dan tidak tahan panas (Almatsier, S., 2001).

Berdasarkan hasil survey dan wawancara dengan ketua Pokja PKK Kelurahan Bareng diperoleh informasi bahwa, masyarakat di wilayah 
RW 8 Kelurahan Bareng dengan jumlah penduduk sebesar 6000 jiwa, hanya sebagian kecil yang memanfaatkan tanaman kelor sebagai bahan makanan. Pemanfaatan Kelor sebagai bahan makanan hanya terbatas untuk diolah menjadi sayur bening saja yang dapat membosankan bila terlalu sering dikonsumsi. Terlebih lagi adanya image masyarakat yang telah berkembang bahwa tanaman Kelor diperuntukkan sebagai bahan memandikan orang meninggal dunia. Kondisi demikian membuat hanya sebagian orang saja yang mau memanfaatkan tanaman Kelor sebagai bahan pangan. Masyarakat RW 8 sebetulnya telah membentuk kelompok wanita tani dan sudah giat dalam memanfaatkan lahan kosong di lingkunngan rumahnya masing-masing untuk dimanfaatkan sebagai tanaman sayuran melalui polybag, namun hanya untuk jenis tanaman tertentu saja, sementara tanaman Kelor belum menjadi perhatian dan hanya dianggap sebagai tanaman pagar yang kurang dimanfaatkan sebagai tanaman pangan. Disamping itu berdasarkan hasil jajak pendapat, diketahui sebagian besar Masyarakat Bareng belum mengetahui bahwa tanaman Kelor mengandung gizi tinggi yang dapat diolah sebagai bahan pangan alternatif. Melihat permasalahan tersebut, maka dipandang perlu untuk dilakukan kegiatan Pengabdian Masyarakat dalam bentuk pengembangan pangan lokal berbahan dasar Tanaman Kelor di wilayah RW 8 Kelurahan Bareng, sebagai salah satu upaya untuk meningkatkan ketahanan pangan bagi masyarakat, khususnya di RW 8 kelurahan Bareng Kota Malang.

\section{METODE}

Kegiatan ini dilakukan dengan cara: 1) pretest-postest, 2) ceramah, 3) diskusi dan tanya jawab, 4) praktek pengolahan makanan, 5) pembelajaran modul

\section{HASIL KEGIATAN}

Masyarakat diberikan materi pelatihan tentang Kebijakan Pangan, Kelor Super Nutrisi, Pemberdayaan Perempuan, Berbagai Resep Olahan Makanan Berbahan Dasar Kelor serta Praktik Pengolahan Berbagai Jenis Makanan dengan Bahan Dasar Tanaman Kelor. Total waktu yang dibutuhkan dalam penyampaian materi

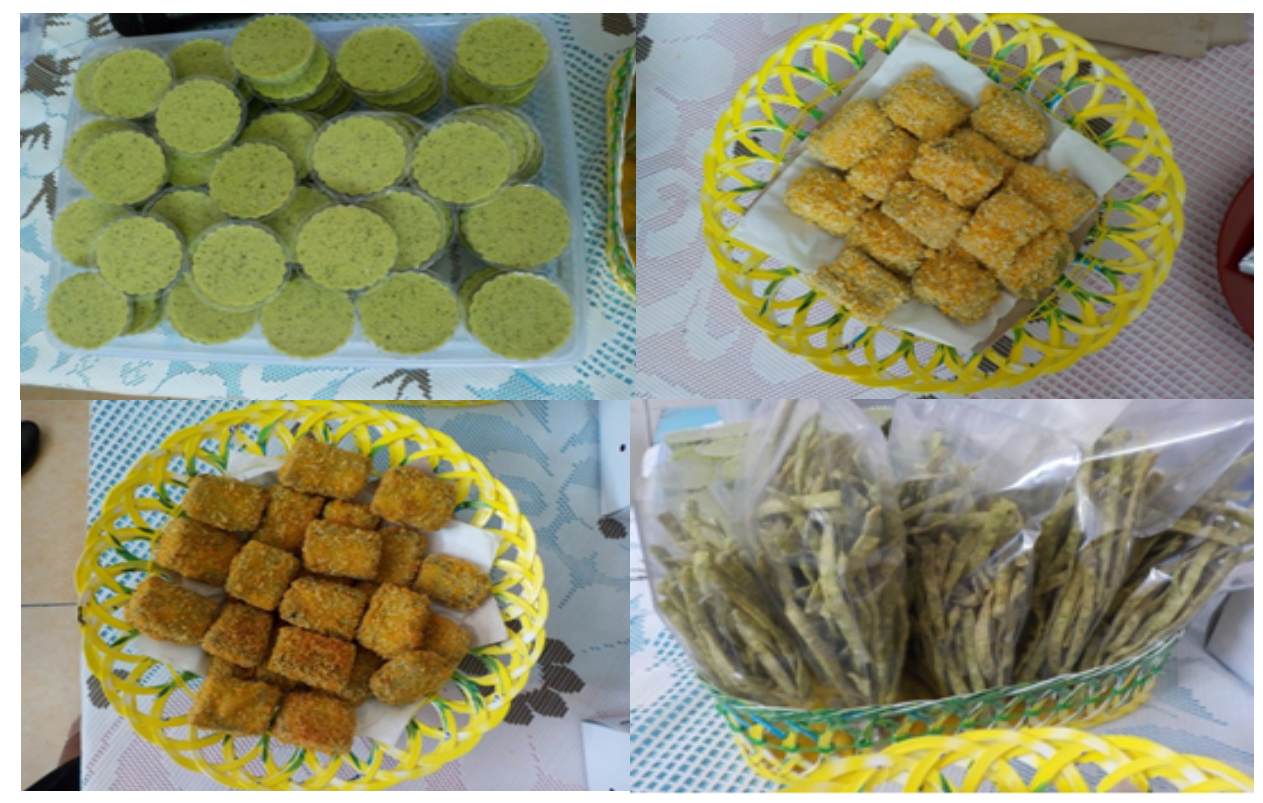

Gambar 1. Hasil Praktik Pengolahan Makanan Berbasis Kelor 
Tabel 1. Nilai Pre-test dan Post-test Pelatihan

\begin{tabular}{llll}
\hline \multirow{2}{*}{\multicolumn{1}{c}{ Materi Pelatihan }} & \multicolumn{2}{c}{ Rerata nilai } & \multirow{2}{*}{ Keterangan } \\
\cline { 2 - 3 } & Pre-test & Post-test & \\
\hline Kandungan gizi tanaman kelor & 69,5 & 82,7 & Peningkatan rerata nilai: 13,2 \\
Bahan makanan bersumber tanaman Kelor & 74,5 & 85 & Peningkatan rerata nilai: 10,5 \\
\hline
\end{tabular}

pelatihan tersebut sebanyak 6 jam dengan pemateri Kepala Kelurahan, Dosen Poltekkes Kemenkes Malang, staf Dinas Ketahanan Kota Malang, Pemberdayaan Perempuan serta Ketua Pokja PKK Kelurahan Bareng. Setelah Peserta pelatihan mendapatkan beberapa materi, selanjutnya dilakukan praktik pengolahan makanan dengan bahan dasar Kelor diantaranya adalah Puding Daun Kelor, Rolade Kelor, Nugget Kelor, dan Stick Kelor.

Minat kader untuk mengikuti program ini sangat tinggi, hal ini terlihat dengan seluruh kader yang diundang sebanyak 25 orang, seluruhnya hadir dan mengikuti pelatihan dengan sungguhsungguh. Selain itu pada saat dilakukan praktik pengolahan makanan berbahan dasar Kelor, seluruh kader dapat mengikuti kegiatan dengan antusias sampai semua kegiatan berakhir.

Kegiatan Pelatihan terbukti dapat meningkatkan pengetahuan masyarakat dalam hal kandungan gizi tanaman kelor, pemanfaatan tanaman Kelor untuk bahan makanan, sebagaimana terlihat dari hasil pre test dan posttest berikut ini.

Tabel 1 menunjukkan pengetahuan seluruh peserta pelatihan mengalami peningkatan pengetahuan tentang kandungan gizi yang terdapat pada tanaman Kelor dan pemanfaatan tanaman Kelor sebagai sumber makanan bernilai gizi tinggi. Disamping terjadi peningkatan pengetahuan, setelah kegiatan pengabmas juga terjadi perubahan perilaku yaitu kader telah mempraktikan pembuatan makanan olahan dari bahan dasar Kelor dan dipasarkan pada lingkungan sekitar RW 8 serta pada even tertentu misalnya ada kegiatan di tingkat kelurahan. Disamping itu Pokja merencanakan Wilayah RW 8 akan dijadikan Ekowisata dengan salah satu andalanya adalah Pembudidayaan tanaman Kelor.

\section{PENUTUP}

Dari kegiatan pemberdayaan masyarakat melalui pengembangan pangan berbahan dasar tanaman Kelor tersebut dapat disimpulkan bahwa, Masyarakat RW 8 Kelurahan Bareng Kota Malang berpotensi mampu mengembangkan tanaman pangan lokal khususnya tanaman kelor. Hal ini terbukti dari kesungguhan yang ditunjukkan dalam mengikuti pelatihan pengembangan pangan berbasis tanaman Kelor. Indikator ini dapat dilihat dari meningkatnya pengetahuan secara bermakna setelah mengikuti Pelatihan. Disamping itu juga dapat dilihat pada saat praktik pengolahan makanan berbahan dasar Kelor, partisipasi sangat baik dan dapat menghasilkan bermacam-macam jenis makanan yang berbahan dasar Kelor, diantaranya Sayur Kelor, Bothok Kelor, Nugget Kelor, Rolade Kelor, Puding Kelor, Stick Kelor. Selain itu peserta pelatihan juga telah mampu memproduksi beberapa jenis makanan olahan Kelor untuk dikomersialkan, meski baru terbatas pada kalangan pokja di Kelurahan Bareng.

\section{DAFTAR PUSTAKA}

Adi, Lukas Trisno. (2006). Tanaman Obat dan Jus Untuk Asam Urat dan Rematik. Jakarta: PT Argo Media

Dewan Ketahanan Pangan Kementerian Pertanian and World food Programme. (2015). Peta Ketahanan dan Kerentanan Pangan Indonesia. 2015.

Mardiana, Lina. (2012). Daun Ajaib Tumpas Penyakit. Jakarta: Penebar Swadaya

Kementerian Kesehatan RI. (2010). Riset Kesehatan Dasar. Jakarta: Kemenkes RI.

Tulus Tambunan. (2010). Ketahanan Pangan Di Indonesia Inti Permasalahan Dan Alternatif Solusinya. Pusat Studi Industri dan UKM. Jakarta: Universitas Trisakti Kadin 